\title{
A Review on Bovine Leptospirosis with Special Reference to Seroprevalence in India
}

\author{
A. Prajapati ${ }^{1 *}$, A. Kushwaha ${ }^{2}$, D. Chayanika ${ }^{1}$, N. Subhashree ${ }^{1}$, P. Varsha ${ }^{1}$, A. Marcia ${ }^{1}$, \\ L. Lahari ${ }^{1}$, P. Shivashankar ${ }^{3}$ and Nikunj Patel ${ }^{3}$ \\ ${ }^{1}$ Division of Bacteriology and Mycology, ${ }^{2}$ Division of Virology, \\ ${ }^{3}$ Immunology Section, Indian Veterinary Research Institute, Izzatnagar, \\ Bareilly-243122, India \\ *Corresponding author
}

A B S T R A C T

\section{Keywords \\ Bovine, Diagnosis, \\ Epidemiology, \\ Leptospirosis, Microscopic Agglutination Test (MAT) \\ Article Info \\ Accepted: \\ 16 March 2018 \\ Available Online: \\ 10 April 2018}

Leptospirosis, a spirochaetal zoonotic disease, has been recognized as an important emerging infectious disease. Leptopsira spp in bovine associated with infertility, abortion and reduced milk production. Recent seroepidemiology of leptopsirosis in bovine population by various workers in India suggest the upsurge in circulating antibodies against leptospira and emergence of new serovar. Present review addresses the issues in the epidemiology with special reference to India, clinical manifestations, diagnosis and management of leptospirosis in bovines.

\section{Introduction}

Leptospirosis has been recognized as an (re)emerging global public health problem occurs in cattle, buffaloes, pig, sheep, goat, dog, horse, etc. Disease is zoonotic in nature, communicable from man to animals and vice versa (Adugna, 2016).

Disease in bovine usually occur in a milder form and responsible for direct or indirect loss in term of abortion and loss of milk production. In India leptospirosis in cattle was first reported by Adinarayan et al., (1960). Since then several reports emerged confirming the prevalence of leptospirosis in bovines from different states of India (Balamurugan et al., 2018; Balamurugan et al., 2016; Mitra et al., 2015; Patel et al., 2014; Blessy et al., 2017; Patel et al., 2017). Extreme weather events such as cyclones and floods, increased rainfall associated with global warming are considered as the factors for the increased incidence of leptospirosis (Lau et al., 2010). 


\section{Organism}

Leptospirosis is caused by the pathogenic spirochetes of the genus Leptospira (Adugna, 2016). Organism is usually about 6-25 $\mu \mathrm{m}$ long and 0.1 to $0.2 \mu \mathrm{m}$ in diameter, highly motile, obligate aerobes. Two axial periplasmic flagella are located in the periplasmic space (Levett, 2001). Term 'Leptospira' was first proposed by Noguchi (1917) based on its thin spiral shape. Organism give optimum growth at a temperature of 28 to $30{ }^{\circ} \mathrm{C}$ and at $\mathrm{pH}$ range 6.8 to 7.4 and usually survived in a moist environment of soils, mud, swamps, streams and rivers. Antigenic structure of bacterium consists of somatic antigens, surface antigen, outer membrane lipopolysaccharides, and flagellar antigens. The outer membrane lipopolysaccharide is the major antigen is a potent immunogen and responsible for serovar specificity. As per phenotypic classification there are two species namely, the $L$. interrogans (pathogenic) and the L. biflexa (non-pathogenic). Pathogenic Leptospira spp. classified into 28 serogroups and over 300 serovars based on LPS antigen (Saito et al., 2013). While the genetic homology in DNA hybridization have been identified 20 species of Leptospira spp. which includes 9 pathogenic, 5 Intermediate and 6 saprophytic species (Smythe et al., 2013). The hostadapted serovars of serogroup Sejroe, mainly serovar Hardjo affects bovines (Mughini-Gras et al., 2014).

\section{Epidemiology of leptospirosis}

Leptospirosis is worldwide distribution and responsible for one of the major cause of reproductive failure in bovine. Disease is more predominate in tropical countries having high rain fall and humidity and, presence of marshy land and paddy grown area (Favero et al., 2017). The urine of infected animals or healthy carriers, aborted fetus and uterine discharges which may contaminate soil, pasture, drinking water and feed is the main source of infection (Adugna, 2016). Leptospiral organisms enter into the body most often through cutaneous or mucosal abrasions. Oral transmission may occur when animals are feeding on contaminated pasture or feedstuffs, or drinking contaminated water. The semen of an infected bull may transmit the disease during natural or artificial insemination (Kiktenko, 1976). Warm and humid climate, slightly alkaline soil, presence of organic matter, existence of animals reservoir hosts like rodents, foxes, jacked, raccoon, wild cat etc mainly influence the disease incidence (Radostits et al., 2009). Leptospires persistently present in proximal renal tubules after recovery and excrete intermittently in the environment for months to years (Adugna, 2016). Even organism can persistent in the mammary gland and excrete in milk after recovery (Thiermann, 1982). Hardjo serovar, is mainly associated with cattle however, serovars Pomona, Icterohaemorrhagiae Hebdomadis, Australis, Bankinang and Grippotyphosa can also be associated to bovine leptospirosis (Balamurugan et al., 2018). Infection in cattle can be divided into two groups of strain; stain adapted to bovine and strain adapted to other domestic and wild animal responsible for incidental infection. Animals are infected through direct contact with animals, animal tissues, body fluids (especially urine), or through indirect contact with contaminated environment (Favero et al., 2017). Exotic pure breeds are more susceptible than indigenous pure breeds and cross breeds (Balakrishnan et al., 2011). In India leptospirosis has been reported from various states by different workers.

\section{Clinical features}

Clinical manifestation of leptospirosis depends on type of serovar, infectious dose, and 
virulence of serovar. It also depends on age, health and immunological status of the host. In bovines, clinical signs are usually mild or inapparent when infected by host-adapted serovars. However, for infections with nonhost-adapted serovars, clinical symptoms may range from mild to severe (Lilenbaum and Martins, 2014).

\section{Acute form}

Acute leptospirosis in these animals is infrequent and has been associated mostly to incidental serovars such as Pomona, Grippotyphosa, and Icterohaemorrhagiae. Calves up to one month of age are generally affected with this form. The disease is characterized by high fever $\left(40.5^{\circ} \mathrm{C}\right.$ to $41.5^{\circ} \mathrm{C}$ ), septicaemia, anorexia, petechiae on mucosa, acute haemolytic anaemia, haemoglobinuria, jaundice, and decrease milk production in adult (Radostits et al., 2009).

Ulceration on the cutaneous and mucous surfaces, subcutaneous oedema, gastroenteritis and cherry red coloured urine are also common finding. Leptospira interrogans serovar Hardjo and Pomona infection in lactating animals result in mastitis with sudden reduction in milk production (Thiermann, 1982). Abortion, stillbirth, premature birth of weak calf, congenital infection, may occur in pregnant animals (Radostits et al., 2009).

\section{Subacute form}

In subacute form animals show clinical expressions as acute but for lesser severity (Adugna, 2016).

\section{Chronic form}

Chronic infections usually involves infection by host-adapted serovars, which can lead to chronic interstitial nephritis, poor reproductive performance, abortion, stillbirth, weak offspring, reduced milk production, and poor growth (Adugna, 2016).

\section{Diagnosis}

Diagnosis is usually based on the history of disease and laboratory confirmations. Standard tests, such as culture isolation of the organism from clinical specimens and the microscopic agglutination test (MAT) are generally employed for diagnosis of infection in most of laboratory due to high specificity. Robust and easy to use diagnostic tests are still lacking for diagnosis of leptospirosis in both humans and animals.

\section{Dark field microscopy}

Leptopsira organism can be visualized and identified in the clinical sample by the use of dark field microscope after silver staining or Wrthin-Starry staining. Immunostaining which requires a primary antibody specific for the serovar can be used to increase the specificity of procedure (Suman and Khalid, 2014)

\section{Isolation and identification of organism}

Leptospira organisms could be isolated from body fluids, mainly urine, tissue from dead animals such as kidney, liver, lungs, brain ((Suman and Khalid, 2014). In suspected abortion cases the agent can be isolated from abortion materials or tissue samples from a freshly aborted fetus kidney, liver and lungs (Monte et al., 2015). Presence of organism in internal organ of fetus indicates maternal infection. But due to the low level of recovery, it is not used as a routine diagnostic method. Liquid and semisolid EllinghausenMcCullough-Johnson-Harris (EMJH) media commonly employed for isolation purposes that are enriched with $1.0 \%$ rabbit serum and bovine serum albumin and supplemented with 5-fluorouracil to prevent saprophytic leptospira growth. 


\section{Seroprevalence of bovine leptospirosis in India}

\begin{tabular}{|c|c|c|c|c|c|}
\hline States & $\begin{array}{l}\text { Sero } \\
\text { prevalence }\end{array}$ & Test used & $\begin{array}{l}\text { Sample } \\
\text { size }\end{array}$ & Serovars & References \\
\hline Odisha & $42.5 \%$ & $\begin{array}{l}\text { Microscopic } \\
\text { agglutination } \\
\text { test (MAT) }\end{array}$ & 120 & $\begin{array}{l}\text { L. Australis (50.9\%); L. } \\
\text { Hardjo }(23.5 \%)\end{array}$ & $\begin{array}{l}\text { Balamurugan } \\
\text { et al., } 2013\end{array}$ \\
\hline Nine districts of Bihar & $9.11 \%$ & DAS-ELISA & 450 & L. Hardjo & $\begin{array}{l}\text { Pandian } \quad \text { et } \\
\text { al., } 2015\end{array}$ \\
\hline $\begin{array}{l}\text { Four districts of South } \\
\text { Gujarat }\end{array}$ & $5.77 \%$ & I-ELISA kit & 398 & L. Hardjo & $\begin{array}{l}\text { Patel et al., } \\
2017\end{array}$ \\
\hline Pondicherry & $\begin{array}{l}36.4 \% \\
\text { and } \\
24.8 \%\end{array}$ & $\begin{array}{l}\text { I-ELISA and } \\
\text { MAT } \\
\text { respectively }\end{array}$ & 250 & $\begin{array}{l}\text { L. Hardajo (49\%); } \\
\text { L. Grippotyphosa } \\
(24.19 \%) ; \\
\text { Pomana (16\%) }\end{array}$ & $\begin{array}{l}\text { Blessy et al., } \\
2017\end{array}$ \\
\hline South Gujarat districts & $12.81 \%$ & MAT & 398 & Pomona $(28.89 \%)$ & $\begin{array}{l}\text { Patel et al., } \\
2014\end{array}$ \\
\hline South Andaman & $69.44 \%$ & MAT & 108 & $\begin{array}{l}\text { Automnalis }(53.70 \%) \\
\text { Sejroe }(28.70 \%) \text { and Hardjo } \\
(22.22 \%\end{array}$ & $\begin{array}{l}\text { Mitra et al., } \\
2015\end{array}$ \\
\hline $\begin{array}{ll}\text { Kokan } & \text { region } \\
\text { Maharastra } & \end{array}$ & $41.04 \%$ & MAT & 575 & $\begin{array}{l}\text { Australis }(23.61 \%) \text { Hardjo } \\
(19.44 \%), \quad \text { Hebdomadis } \\
(16.67 \%), \quad \text { Bankinang } \\
(15.28 \%), \\
\text { Icterohaemorrhagiae } \\
(14.58 \%)\end{array}$ & $\begin{array}{l}\text { Balamurugan } \\
\text { et al., } 2016\end{array}$ \\
\hline $\begin{array}{l}\text { Maharashtra, Gujarat, } \\
\text { Andhra Pradesh, } \\
\text { Telangana, Karnataka, } \\
\text { Tamil Nadu, Punjab, } \\
\text { Haryana, } \\
\text { Chhattisgarh, Sikkim } \\
\text { and Uttarakhand }\end{array}$ & $70.51 \%$ & MAT & 373 & $\begin{array}{l}\text { Hardjo } \quad(27.76 \%), \\
\text { Pyrogenes } \quad(18.63 \%), \\
\text { Canicola and Javanica } \\
(17.49 \%), \quad \text { Hebdomadis } \\
(17.11 \%), \\
\text { Panama Shermani and } \\
\text { Djasiman }(16.35 \%)\end{array}$ & $\begin{array}{l}\text { Balamurugan } \\
\text { et al., } 2018\end{array}$ \\
\hline
\end{tabular}

Antimicrobial agents should also be added to inhibit the growth of contaminants, but allow the multiplication of Leptospira spp. Leptospira grow beneath the surface of the semisolid medium and form a discrete zone, known as a Dinger's ring.

\section{Microscopic Agglutination Test (MAT)}

Test is the most widely used for diagnosis and epidemiological surveillance in India and worldwide. More confirmative diagnosis requires the use of both acute and convalescent sera, because of the frequent low or possibly negative MAT titres in animals recently infected with L. Hardjo. Crossreactive antibodies caused by exposure to leptospires of the same serogroup also common.

The MAT has the disadvantages that it is tedious and time consuming and requires the live culture which imposes a risk of human infection. Test is also unable to differentiate between titres after vaccination and those after natural infection, since the titres may be of similar magnitude (Pinto et al., 2016). 


\section{Enzyme-Linked Immunosorbent Assay} (ELISA)

The ELISA test is highly sensitive, easy to perform and can measure $\operatorname{IgM}$ and $\operatorname{IgG}$ antibody levels in serum (Suman and Khalid, 2014). Advantages of test include uses of killed antigen and ability to measure different immunoglobulin classes. ELISA based on detection of $\operatorname{IgM}$ is able to detect recent infection of leptospires in cattle. ELISA-IgG is more sensitive and specificity than MAT (O'Keefe, 2002; Patel et al., 2017).

\section{Direct or Indirect Fluorescent Antibody Test (FAT)}

The FAT is a very useful technique for demonstrating leptospires antigen in tissues from infected animals and aborted fetuses material (Dhaliwal et al., 1996). FAT is particular important to demonstrating the presence of leptospires in autolysed materials (Smith et al., 1966). It can also employ in urine sample or cultured samples for fast and accurate diagnosis (Rajeev et al., 2010).

\section{Restriction Endonuclease Analysis (REA) and Pulsed-Field Gel Electrophoresis (PFGE)}

REA can be used to type leptospires that are serologically undistinguished. In this technique, a large number of fragments are generated after restriction with an endonuclease enzyme such as EcoRI, HhaI, or HindIII (Eljalii and Ali, 2006). Recently, pulsed-field gel electrophoresis (PFGE) has also been introduced for identification and an epidemiological study of leptospiral isolates (Galloway and Levett, 2008).

\section{In situ DNA hybridisation}

It is rapid, specific and sensitive means for diagnosis of leptospirosis (De Brito et al., 2006). Le Febvre, (1987) described a DNA probe that could identify $L$. Hardjobovis in cattle. DNA hybridisation was more sensitive than either FAT or culture techniques for the diagnosis of bovine leptospirosis (Herrmann, 1993).

Genome specific amplification and identification

The PCR is a rapid, reliable and sensitive test for the diagnosis of leptospirosis. The application of the PCR for the diagnosis of leptospirosis has been reported by different workers based on specific gene targets, most frequently $16 \mathrm{~S}$ or $23 \mathrm{~S}$ rRNA genes (Merien $e t$ $a l ., 1992)$ and repetitive elements (Zuerner $e t$ al., 1995). A nested PCR with primers derived from the LipL32 sequence has been reported by Nassi et al., (2003). The product obtain after amplification were subjected to REA and the profiles correlated well with phylogenetic relationships between these serovars. The main concern with PCR assay is the false-positive results which are caused by contamination with previously amplified DNA or target DNA.

\section{Prevention and control}

Various control measures include that minimize the accidental infection of cattle by carrier and reservoir hosts, and minimize spread of infection within a herd by vaccination or combined vaccination with aim to prevent reproductive losses, renal colonization and urinary shedding of organism (Martins and Lilenbaum, 2017). Cattle should be separated from pigs and sheep, and should not allow for gazing near ponds and marshes. Vaccination of susceptible animals is most economically way to control disease in large organized farm. Inactivated vaccine is available for commercial use in some countries. It requires booster immunization either annually or 6 month interval to raise protective immunity depending upon herd structure and risk of 
exposure (Bolin, 2003; Wang and Węgrzyn, 2007). Regular screening of bulls is also important and if they are infected they should not be used naturally or for artificial insemination. Quarantine and screening of newly introduced animals is important before allowing them to enter the herd. Damp areas near the farm should be drained or fenced and use suitable disinfection in farm. Since rats and other wild animals may act as a source of infection, contact between them and farm animals should be controlled by using rat bait and fencing of farm (Martins and Lilenbaum, 2017).

\section{References}

Adinarayanan, N., Jain, N.C., Chandiramani, N.K. and Hajela, S.K. 1960. Studies on leptospirosis among bovines in India. Indian Vet. J. 37:251-254.

Adugna, S. 2016. A Review of Bovine Leptospirosis. Eur. J. Appl. Sci., 8: 347355.

Balakrishnan, G., Roy, G.P., Govindarajan, R., Ramaswamy, V., and Murali Manohar, B. 2011. Seroepidemiological studies on leptospirosis among bovines in organized farm. International $J$. Agro. Vet. Med. Sci., 5(6): 511-519.

Balamurugan, V., Alamuri, A., Bharathkumar, K. Patil, S.S., Govindaraj, G.N., Nagalingam, M., Krishnamoorthy, P., Rahman, H. and Shome, B.R. 2018. Prevalence of Leptospira serogroup - specific antibodies in cattle associated with reproductive problems in endemic states of India. Trop. Anim. Health. Prod. doi.org/10.1007/s11250-018-1540-8.

Balamurugan, V., Thirumalesh, S.R.A., Sridevi, R., Mohandoss, N., Govindaraj, G., Hemadri, D., Gajendragad, M.R. and Rahman. H. 2013. Seroprevalence of bovine leptospirosis in Odisha, India. World J. Vet. Sci., 1: 192.
Balamurugan, V., Thirumalesh, S.R.A., Veena, S., Alamuri, A., Nagalingam, M., Sridevi, R., Govindaraj, G., Hemadri, D., Gajendragad, M.R. and Rahman, H. 2016. Investigation on the distribution of Leptospira serovars and its prevalence in bovine in Konkan region, Maharashtra, India. Adv. Anim. Vet. Sci., 4: 19-26.

Blessy, R., Sumanth, K., Raghavan, M.P., Prabhakar, X.A., Hirak, K.M., Sangeetha, B., Nobal, R. and Mouttou, V.S. 2017. Comparative study on serodiagnosis of bovine leptospirosis by microagglutination test (MAT) and Indirect ELISA. Int. J. Curr. Microbiol. App. Sci. 6: 1551-1558.

Bolin C.A. 2003. Diagnosis and control of bovine leptospirosis. Proceedings of the 6th Western Dairy Management Conference. March 12-14, 2003 Reno, NV-156.

De Brito, T., Menezes, L.F., Lima, D.M., Lourenço, S., Silva, A.M. and Alves, V.A. 2006. Immunohistochemical and in situ hybridization studies of the liver and kidney in human leptospirosis. Virchows Arch. 448(5):576-83.

Dhaliwal, G.S., Murrary, R.D., Dobson, H., Montgomery, J. and Ellis, W.A. 1996. Presence of antigen and antibodies in serum and genital discharges of cows from dairy herds naturally infected with Leptospira interrogans serovar Hardjo. Res.Vet. Sci., 60: 163-7.

Eljalii, I.M. and Ali, A.S. 2006. Differentiation of leptospiral serovars by restriction endonucleases analysis. $J$. Hellenic Vet. Med. Soci., 57(4): 297301.

Favero, J.F., Araujo, H.L., Lilenbaum W., Machado G., Tonin A.A., Baldissera M.D., Stefani L.M. and Silva, A.D. 2017. Bovine leptospirosis: Prevalence, associated risk factors for infection and 
their cause-effect relation. Microbial Pathogenesis., 107:149-154.

Galloway, R.L. and Levett, P.N. 2008. Evaluation of a modified pulsed-field gel electrophoresis approach for the identification of Leptospira serovars. Am. J. Trop. Med. Hyg. 78: 628-32.

Herrmann, J.L. 1993. Genomic techniques for identification of Leptospira strains. Pathol. Biol. 41: 943-50.

Kiktenko, V.S. 1976. Leptospirosis infection through insemination of animals. J. Hyg. Epidemiol. Microbiol. Immunol., 21: 207-213.

Lau, C.L., Lee, D., Scott, S.B., Weinstein, C.P. 2010. Climate change, flooding, urbanisation and leptospirosis: fuelling the fire? Trans. R. Soc. Trop. Med. Hyg., 104: 631-638.

Le Febvre R.B. 1987. DNA Probe for Detection of the Leptospira interrogans Serovar Hardjo Genotype Hardjo-Bovis. J. Clinical Microbiol., 2236-2238.

Levett, P.N. 2001. "Leptospirosis," Clinical Microbiol. Rev., 14: 296-326.

Lilenbaum W. and Martins G. 2014. Leptospirosis in Cattle: A challenging scenario for the understanding of the epidemiology, Trans. Emerg. Dis., 61: 63-68.

Martins G. and Lilenbaum W. 2017. Control of bovine leptospirosis: Aspects for consideration in a tropical environment. Res. Vet. Sci., 112: 156-160.

Merien, F., Amouriaux, P., Perolat, P., Baranton, G. and Girons I. 1992. Polymerase chain reaction for detection of Leptospira spp. in clinical samples. $J$. Clinical Microbiol., 30: 2219-24.

Mitra, J., Chowdhury, S. and Pattanayak, S. 2015. Sero- prevalence of bovine leptospirosis in south andaman islands, India. Explor. Anim. Med. Res., 5: 96101.

Monte, L.G., Ridieri, K.F., Jorge, S., Oliveira, N.R., Hartwig, D.D., Amaral, M.G.,
Hartleben, C.P. and Dellagostin, O.A. 2015. Immunological and molecular characterization of Leptospira interrogans isolated from a bovine foetus. Comp. Immunol. Microbiol. Infect. Dis., 40, 41-5.

Mughini-Gras, L., Bonfanti, L., Natale, A., Comin, A., Ferronato, A., Greca, E.L., Patregnani, T., Lucchese, L. and Marangon, S. 2014. Application of an integrated outbreak management plan for the control of leptospirosis in dairy cattle herds, Epidemiol. Infect. 142: 1172-1181.

Nassi, F.L., Seixas, F.K., Jouglard, S.D., Simionatto, S., Silva, E.F., Seyffert, N., Brod, C.S. and Dellagostin, O.A. 2003. Leptospirosis diagnosis using nested PCR. Brazil. J. Microbiol., 34:90-92.

Noguchi, H. (1917). Spirochaeta icterohaemorrhagiae in American wild rats and its relation to the Japanese and European strains. J. Exp. Med., 25:755763.

O'Keefe. J.S. 2002. A brief review on the laboratory diagnosis of leptospirosis. New Zealand Vet. J., 50: 9-13.

Pandian, S.J., Ray, P.K., Chandran, P.C. and Kumar, M. 2015. Seroprevalence of Brucella abortus and Leptospira Hardjo in cattle. Vet. World., 8: 217-220.

Patel J.M., Prasad, M.C., Vihol, P.D., Kalyani, H., Prajapati, M.G., Parmar, H.C., Varia, R.D. and Patel, K.M. 2017. Seroprevalence of Leptospira Hardjo in cattle of Gujarat, India. Int. J. Curr. Microbiol. App. Sci., 6: 1304-1310.

Patel, J.M., Vihol, P.D., Prasd, M.C., Kalyani, I.H., Raval, J.K. and Patel, K.M., Thirumalesh, S.R.A. and Balamurugan, V. 2014. Seroepidemiological pattern of leptospirosis in bovine of South Gujarat, India, Vet. World., 7: 999.

Pinto P.S., Libonat H., Penna B., and Lilenbaum W. 2016. A systematic review on the microscopic agglutination 
test seroepidemiology of bovine leptospirosis in Latin America. Trop. Anim. Health. Prod., 48:239-248.

Radostits, O.M., Gay, C.C., Hinchcliff, K.W. and Constable, P.D. 2009. Veterinary Medicine, a text book of the diseases of cattle, horse, sheep, pigs, and goat. Saunders Elsevier. Pp: 1094-1105.

Rajeev, S., Berghaus, R.D., Overton, M.W., Pence, M.E. and Baldwin, C.A.2010. Comparison of fluorescent antibody and microscopic agglutination testing for Leptospira in pregnant and nonpregnant cows. J. Vet. Diagn. Invest., 22(1):51-4.

Saito, M., Villanueva, S.Y., Kawamura, Y., Lida, K., Tomida, J., Kanemaru, T., Kohno, E., Miyahara, S., Umeda, A., Amako, K., Gloriani, N.G. and Yoshida, S. 2013. Leptospira idonii sp. nov., isolated from environmental water. Int. J. Syst. Evol. Microbiol., 63: 24572462.

Smith, C.R., Ketterer, P.J., McGowan, M.R. and Coreny, B.G.1994. A review of laboratory techniques and their use in the diagnosis of Leptospira interrogans serovar hardjo infection in cattle. Australian Vet. J., 71: 290-294.
Smythe, L., Adler, B., Hartskeerl, R.A., Galloway, R.L., Turenne, C.Y. and Levett, P.N. 2013. Classification of Leptospira genomo species 1, 3, 4 and 5 as Leptospira alstonii sp. nov., Leptospira vanthielii sp. nov., Leptospiraerpstrae sp. nov. and Leptospira yanagawae sp. nov., respectively. Int. J. Syst. Evol. Microbiol., 63: 1859-62.

Suman, V.B. and Khalid P. 2014. Leptospirosis diagnosis: competency of various laboratory tests. J. Clin. Diagn. Res. 8: 199-202.

Thiermann, A.B. 1982. Bovine Leptospirosis: Experimental leptospiral infection in pregnant cattle with organisms of the Hebdomendis serogroups. Am. J. Vet. Res., 43: 780-784.

Wang, Z. and Węgrzyn A. 2007. Leptospirosis vaccines. Microb. Cell. Fact., 6: 39.

Zuerner, R.L., Alt, D. and Bolin, C.A. 1995. IS1533-based PCR assay for identification of Leptospira interrogans sensu lato serovars. J. Clinical Microbiol., 33: 3284-9.

\section{How to cite this article:}

Prajapati, A., A. Kushwaha, D. Chayanika, N. Subhashree, P. Varsha, A. Marcia, L. Lahari, P. Shivashankar and Nikunj Patel. 2018. A Review on Bovine Leptospirosis with Special Reference to Seroprevalence in India. Int.J.Curr.Microbiol.App.Sci. 7(04): 1813-1820. doi: https://doi.org/10.20546/ijcmas.2018.704.205 